http://jmscr.igmpublication.org/home/ ISSN (e)-2347-176x ISSN (p) 2455-0450

crossref DOI: https://dx.doi.org/10.18535/jmscr/v8i1.47

\title{
Our Experience in Incisional Hernia Repair with Polypropylene mesh at VIMSAR, Burla
}

\author{
Authors \\ P. Hembram ${ }^{1}$, B.C. Pal ${ }^{2}$ \\ ${ }^{1}$ Assistant Professor, Department of General Surgery, VIMSAR, Burla \\ ${ }^{2}$ Senior Resident, Department of General Surgery, VIMSAR, Burla
}

\begin{abstract}
Introduction: A patient with Incisional hernia is a living document of failure of surgical skill. . They continue to be one of the more common complications of abdominal surgeries and a significant source of morbidity and loss of time from productive employment. The incidence of Incisional hernia varies from 2$11 \%$. Most studies suggest that polypropylene mesh is still the most widely used prosthetic material for repair of incision hernias with satisfactory results and least recurrence. The present study on incisional hernia repair using polypropylene mesh was conducted in our institution and postoperative results are observed.
\end{abstract}

\section{Aims and Objective}

- To perform repair of incisional hernia using polypropylene mesh.

- To compile the results of the repair in terms of postoperative morbidity, wound infection, mesh rejection, return to normal activities, recurrence and patient compliance.

Materials and Methods: The present work was conducted in the Department of General Surgery VSSIMSAR, BURLA, Odisha during period from November 2016 to October 2019. Total 25 cases of incisional hernia were included in this study out of which 20 polypropylene mesh repair were done. In the 2 years study period patients were asked to report at $1^{\text {st }}$ month, $6^{\text {th }}$ month, $1^{\text {st }}$ year and $2^{\text {nd }}$ year to assess wound infection, status of ambulation, residual pain, mesh rejection and recurrence.

Observations: Out of total 25 patients 12 (48\%) patients were male and 13 (52\%) were female. Maximum no of incisional hernia cases were found in more than 50 years age (36\%). We found large hernia 7 (28\%), medium $10(40 \%)$ and small in $5(20 \%)$ of cases, 19 (76\%) cases were symptomatic and 6 (24\%) asymptomatic. In our series $50 \%$ patients could do their routine activity on the 2 nd day of operation and only $4(20 \%)$ patients required 4 days to resume their routine activities. $50 \%$ of our patients resume full activities by the end of $3 r d$ week., the post-operative complications have remained very low. Post-operative wound infection was $10 \%$. Fifteen per cent patients had residual pain in the $1^{\text {st }}$ month. Residual pain was controlled conservatively and none required removal of mesh. We have not encountered a single instance of mesh rejection.

Conclusion: It can be concluded that use of polypropylene mesh is a fairly easy procedure. Wound defects of different sizes could be properly patched. Tissue acceptance and pressure endurance of the graft is very good. Patient compliance is satisfactory. This procedure is complication free technically easy and recurrence free procedure hence is surely recommended for repair of incisional hernia. 


\section{Introduction}

A patient with Incisional hernia is a living document of failure of surgical skill, a constant reminder of the need for improving our understanding and development of basic concept in this field ${ }^{1}$. Incisional hernias are unique in that they are the only abdominal wall hernias that are considered to be iatrogenic. They continue to be one of the common complications of abdominal surgeries and a significant source of morbidity and loss of time from productive employment. Many of these patients will alter their life styles so as not to exacerbate their abdominal wall hernia eliminating the potential for gainful employment leading to incalculable economic impact. The incidence of Incisional hernia varies from $2-11 \%^{2}$ depending upon several factors like preoperative status of the patients type and site of abdominal incision, operative technique of abdominal closure and post-operative state of the patient. Though many different approaches have been described for the repair of incisional hernia ranging from resuturing, anatomical repair to darning, no single technique is satisfactory for all incisional hernias, resulting in high failure rate and recurrence $(20 \%$ $46 \%)^{3}$. Small incisional hernias are satisfactorily repaired using the patients' own tissues and conventional surgical technique. But massive hernias with large musculo-fascial defects in the abdominal wall are very debilitating, prone to complications and poorly controlled by external supports. Patients and surgeons alike are discouraged by repeated and often unsuccessful attempts at repair, with many patients confined to restricted lifestyle ${ }^{4}$. Large incisional hernias require prosthesis for a successful repair ${ }^{5}$. Many prosthetic techniques have been described but agreement on the preferred method is lacking. An important advance in the lessening of tissue tension was the pioneering works of Usher and associates, who first reported the use of Marlex (Monofilament knitted polypropylene) mesh in the repair of Incisional hernias in $1985^{6,7}$. Since that time number of other synthetic materials have been utilised for the repair of large incisional hernias. Most studies suggest that polypropylene mesh is still the most widely used prosthetic material for repair of incision hernias with satisfactory results and least recurrence 4,8 . Keeping in view of the above facts the present study on incisional hernia repair using polypropylene mesh was conducted in our institution and postoperative results are observed.

\section{Aims and Objective}

- To perform repair of incisional hernia using polypropylene mesh.

- To compile the results of the repair in terms of postoperative morbidity, wound infection, mesh rejection, return to normal activities, recurrence and patient compliance.

\section{Materials and Methods}

The present work was conducted in the Department of General Surgery VSSIMSAR, BURLA, Odisha during period from November 2016 to October 2019. Total 25 cases of incisional hernia were included in this study out of which 20 polypropylene mesh repair were done. The following types of patients were not considered for polypropylene mesh repair.

- Incisional hernia that have not crossed one year after the operation that caused hernia or after previous failed attempt at repair.

- Small incisional hernias $<5 \mathrm{~cm}$ in size.

- Incisional hernias having infections or sinuses.

- Patients not willing to take the graft

After taking thorough history and consent and proper preoperative evaluation 25 cases of incisional hernia were taken up for study. Five cases were small $(<5 \mathrm{~cm}$ in size) hernia which were repaired by anatomical closure using polypropylene suture. The other 20 cases which were $>5 \mathrm{~cm}$ in size were repaired with the use of polypropylene mesh by putting them at different levels (onlay or subfascial).The operation was carried out in the usual method of scar excision, excision of excess fibrous tissue, sac dissection 
and mobilisation of the layers of the abdomen up to a comfortable margin of 5 to $7 \mathrm{cms}$. We have not encountered any difficulty in this process of surgical dissection. Intrabdominal viscera were inspected and appropriate lysis of adhesion or, otherwise were carried out as necessary. Parietal peritoneal margin was closed with polypropylene sutures meticulously. The polypropylene mesh sized to match the defect was fixed at the site of hernial deficiency area, so as to overlap 3 to $5 \mathrm{cms}$ at all sides; mesh fixation was done by interrupted polypropylene suture. Abdominal layers closed with suction vacuum drainage. Early ambulation was allowed in all cases. From the 2nd postoperative day onward, patients were allowed oral diet. In all cases sutures were removed on 9th post-operative day and patients returned home. In the 2 years study period patients were asked to report at $1^{\text {st }}$ month, $6^{\text {th }}$ month, $1^{\text {st }}$ year and $2^{\text {nd }}$ year to assess wound infection, status of ambulation, residual pain, mesh rejection and recurrence.

\section{Observations}

Table I: Age and Sex Distribution

\begin{tabular}{|l|c|c|c|}
\hline AGE in years & MALE $(\%)$ & FEMALE $(\%)$ & TOTAL $(\%)$ \\
\hline$<30$ YRS & $0(0 \%)$ & $2(8 \%)$ & $2(8 \%)$ \\
\hline $30-40$ & $1(4 \%)$ & $5(20 \%)$ & $6(24 \%)$ \\
\hline $40-50$ & $5(20 \%)$ & $3(12 \%)$ & $8(32 \%)$ \\
\hline$>50$ & $6(24 \%)$ & $3(12 \%)$ & $9(36 \%)$ \\
\hline TOTAL & $12(48 \%)$ & $13(52 \%)$ & $25(100 \%)$ \\
\hline
\end{tabular}

Table II- Preoperative Patient Status

\begin{tabular}{|c|c|c|c|}
\hline \multicolumn{3}{|l|}{ PREOPERATIVE PATIENT VARIABLES } & NO. OF CASES (\%) \\
\hline \multirow{4}{*}{ PRESENTATION } & \multicolumn{2}{|l|}{ PAIN \& DISCOMFORT } & $10(40 \%)$ \\
\hline & \multicolumn{2}{|c|}{ INTERMITTENT OBSTRUCTION } & $4(16 \%)$ \\
\hline & \multicolumn{2}{|l|}{ RECURRENCE } & $5(20 \%)$ \\
\hline & \multicolumn{2}{|l|}{ ASSYMPTOMATIC } & $6(24 \%)$ \\
\hline \multirow{4}{*}{ SIZE } & \multicolumn{2}{|l|}{ LARGE( $>10 \mathrm{cms})$} & $7(28 \%)$ \\
\hline & \multicolumn{2}{|l|}{ MEDIUM( $5-10 \mathrm{cms})$} & $10(40 \%)$ \\
\hline & \multicolumn{2}{|l|}{ SMALL $(<5 \mathrm{cms})$} & $5(20 \%)$ \\
\hline & \multicolumn{2}{|l|}{ MULTIPLE } & $3(12 \%)$ \\
\hline \multirow{5}{*}{$\begin{array}{l}\text { TIME INTERVAL } \\
\text { BPETWEEN } \\
\text { APPEANCE OF INCISIONAL } \\
\text { HERNIA AND INDEX SURGERY }\end{array}$} & \multicolumn{2}{|l|}{$<1$ YEAR } & $7(28 \%)$ \\
\hline & \multicolumn{2}{|l|}{ 1-3YEAR } & $10(40 \%)$ \\
\hline & \multicolumn{2}{|l|}{$\begin{array}{l}\text { 3-5 YEAR } \\
\text { 5-7 YEAR }\end{array}$} & $2(8 \%)$ \\
\hline & \multirow{2}{*}{\multicolumn{2}{|c|}{$\frac{5-7 \mathrm{YEAR}}{>7 \mathrm{YEAR}}$}} & $4(16 \%)$ \\
\hline & & & $2(8 \%)$ \\
\hline \multirow{11}{*}{ CAUSAL FACTORS } & \multirow[t]{3}{*}{ PATIENT FACTORS } & MEAN AGE & 52.5 YRS \\
\hline & & OBESITY & $10(40 \%)$ \\
\hline & & JAUNDICE & $1(4 \%)$ \\
\hline & \multirow{3}{*}{$\begin{array}{l}\text { INCISION OF INDEX } \\
\text { SURGERY }\end{array}$} & MIDLINE & $15(60 \%)$ \\
\hline & & PARAMEDIAN & $8(32 \%)$ \\
\hline & & TRANSVERSE & $2(8 \%)$ \\
\hline & \multirow[t]{2}{*}{ TYPE OF SURGERY } & ELECTIVE & $10(40 \%)$ \\
\hline & & EMERGENCY & $15(60 \%)$ \\
\hline & \multirow{3}{*}{$\begin{array}{l}\text { POST } \\
\text { COMPLICATIONS }\end{array}$} & CHEST INFECTION & $6(24 \%)$ \\
\hline & & ABDOMINAL DISTENSION & $2(8 \%)$ \\
\hline & & SURGICAL SITE INFECTION & $14(56 \%)$ \\
\hline
\end{tabular}

Table III- Surgical Approach

\begin{tabular}{|c|c|c|}
\hline \multicolumn{2}{|l|}{ TYPE OF SURGERY } & NO. OF CASES (\%) \\
\hline \multicolumn{2}{|l|}{ EXCISION OF OLD SCAR } & ALL CASES \\
\hline \multicolumn{2}{|c|}{$\begin{array}{l}\text { MASS CLOSURE WITH NO } 1 \text { POLYPROPYLENE ( SIZE OF } \\
\text { DEFECT }<5 \mathrm{cms} \text { ) }\end{array}$} & $3(12 \%)$ \\
\hline \multicolumn{2}{|c|}{$\begin{array}{l}\text { MAYO'S DOUBLE BREASTED TECHNIQUE ( SIZE OF } \\
\text { DEFECT }<5 \mathrm{cms} \text { ) }\end{array}$} & $2(8 \%)$ \\
\hline \multirow{2}{*}{$\begin{array}{l}\text { POLYPROPYLENE MESH REPAIR } \\
\text { (SIZE OF DEFECT }<5 \mathrm{cms} \text { ) }\end{array}$} & ONLAY & $10(40 \%)$ \\
\hline & SUBFASCIAL & $10(40 \%)$ \\
\hline
\end{tabular}


Table IV- Post Operative Outcomes of Patients with Polypropylene Mesh Repair

\begin{tabular}{|c|c|c|}
\hline VARIABLES & TIME & NO. OF CASES $(\%)$ \\
\hline \multirow{4}{*}{$\begin{array}{l}\text { TIME } \\
\text { AMBULATION } \\
\text { (PERSONAL ROUTINE } \\
\text { WORK) }\end{array}$} & DAY 1 & $4(20 \%)$ \\
\hline & DAY 2 & $10(50 \%)$ \\
\hline & DAY 3 & $16(80 \%)$ \\
\hline & DAY 4 & $20(100 \%)$ \\
\hline \multirow{3}{*}{$\begin{array}{l}\text { RETURN TO ACTIVE } \\
\text { LIFE } \\
\end{array}$} & 2 WEEKS & $5(25 \%)$ \\
\hline & 3 WEEKS & $10(50 \%)$ \\
\hline & 4 WEEKS & $5(25 \%)$ \\
\hline \multirow{4}{*}{ WOUND INFECTION } & $1 \mathrm{MONTH}$ & $2(10 \%)$ \\
\hline & 6 MONTHS & $0(0 \%)$ \\
\hline & 1YEAR & $0(0 \%)$ \\
\hline & 2 YEARS & $0(0 \%)$ \\
\hline \multirow{4}{*}{ RESIDUAL PAIN } & $1 \mathrm{MONTH}$ & $3(15 \%)$ \\
\hline & 6 MONTHS & $0(0 \%)$ \\
\hline & 1YEAR & $0(0 \%)$ \\
\hline & 2 YEARS & $0(0 \%)$ \\
\hline \multirow{4}{*}{ MESH REJECTION } & $1 \mathrm{MONTH}$ & $0(0 \%)$ \\
\hline & $1 \mathrm{MONTH}$ & $0(0 \%)$ \\
\hline & 1YEAR & $0(0 \%)$ \\
\hline & 2 YEARS & $0(0 \%)$ \\
\hline \multirow{4}{*}{ RECURRENCE } & $1 \mathrm{MONTH}$ & $0(0 \%)$ \\
\hline & $1 \mathrm{MONTH}$ & $0(0 \%)$ \\
\hline & 1YEAR & $0(0 \%)$ \\
\hline & 2YEARS & $0(0 \%)$ \\
\hline
\end{tabular}

\section{Discussions}

Surgeons by nature of their crafts invariably damage the abdominal wall giving an incision over it to venture the intra-abdominal structures and an incisional hernia is the outcome of it. A recurrence after repair of an incisional hernia as found in literature are typically in the $30 \%$ to $50 \%$ range ${ }^{3,4,9,10}$. This failure in repair of incisional hernia is due to two main reasons.

1. The repair under tension.

2. Use of defective suture material.

To overcome the problems of tension on the suture line various surgeons have tried various methods of repair, like darning or patching the defect with natural tissues, biologic materials, metals or synthetic sheets or weaves. When surgeons sought for sheets of natural tissues, no real progress made until modern synthetic polymer plastic, in forms of sheets of woven or knitted mesh of polyamide and newer polypropylene became available. When Francis Usher $^{11,12}$ introduced polypropylene mesh in 1960 , a new era began during which, when used in incisional hernias produced excellent results. The material is universally available, is easily cut to the required shape, is flexible and moulds itself to the body creases because of the method of double knitting, which interlinks each junction to produce bidirectional elastic properties. It is very strong, and is shown to be resistant; to infection nontoxic and non-oncogenic. The threads are monofilament, extremely smooth, inert and so elicit little tissue reaction consequently they are not rejected, even in the presence of infection collagen tissue can be laid down through the interstices of the weave, so that the material is incorporated into healthy new tissue.

Table I shows out of total 25 patients 12 (48\%) patients were male and $13(52 \%)$ were female. This observation contrasts the other authors observation (Buckmall et $\mathrm{al}^{13}$, Houck et $\mathrm{al}^{14}$, Lamount et $\mathrm{al}^{3}$ where male gender predominate the female. Here in our observation it may be due to more number of caesarean section done by lower midline incisional and more no of female obese patients and lack of postpartum physiotherapy. In this series as shown in table I, maximum no of incisional hernia cases were found in more than 50 years age $(36 \%)$. This is consistent with the observation of Ellis et $\mathrm{al}^{15}$, Lamount et $\mathrm{al}^{3}$.

Most patients undergoing repair of incisional hernia do so only after the hernia has become significant size and the timing of repair is often related to the severity of patient's symptoms (Mudge et $\mathrm{al}^{16}$ ). In consistent with him, as shown in table II, we found large hernia 7 (28\%), medium $10(40 \%)$ and small in $5(20 \%)$ of cases. 
Most of patients were also symptomatic as shown in table II. We found in 19 (76\%) cases were symptomatic and $6(24 \%)$ asymptomatic. Mudge et $\mathrm{al}^{16}$ observed that more than half of the incisional hernias develop later than 1 year after the index operation. They also observed that hernias which develop within 3 years of operation are larger and troublesome. Our observation as shown in table II is also similar. We found in 18 $(72 \%)$ patients hernia appeared after 1 year and in $17(68 \%)$ patients the hernia appeared within 3 years postoperatively which were larger $(>5 \mathrm{cms})$ in size. Predisposing factors include obesity, old age, abdominal distension, post-operative pulmonary complication; male are gender and Jaundice (Bucknall et $\mathrm{al}^{13}$, Lamount et $\mathrm{al}^{3}$ ). We found the mean age $>50$ years, obesity in 10 $(40 \%)$ cases, jaundice in $1(4 \%)$ case, abdominal distension in $2(8 \%)$ cases. We also found some specific factors that relate to the performance of the index operation. Out of the 25 cases, $15(60 \%)$ were emergency surgeries and 10(40\%) were elective ones. Regarding the type of incision given there were midline incision in $15(60 \%)$ cases, Para median in $8(32 \%)$ and transverse in $2(8 \%)$ cases. Among these 25 cases 14 cases $(56 \%)$ had surgical site infection and $2(8 \%)$ had abdominal distension and $6(24 \%)$ had chest infection. These findings also coincide with the findings of previous authors, where they found incisional hernia more common after midline as opposed to transverse incisions (Read et $\mathrm{al}^{17}$, Stoppa etal ${ }^{18}$ ).

In recent years various surgeons have used polypropylene mesh in various ways to repair incisional hernias. In all our cases excision of the old scar was done. In 3 cases (12\%) the defects were closed with no 1 polypropylene suture after defining the aponeurosis which came together without tension. In 2 cases (8\%) Mayo's double breasted technique was adopted where the incision was transverse in rest $20(80 \%)$ large defects, polypropylene mesh repair was done. The mesh used was knitted polypropylene. Two methods of repair were utilised according to the suitability of the cases $\left(\right.$ Larson $\mathrm{GM}$ et $\mathrm{al}^{8}$ ). Out of 20 mesh repair, in $10(50 \%)$ cases the mesh was placed extra peritoneally in subfascial plane and in rest $10(50 \%)$ cases the mesh was fixed as onlay.

As shown in table IV in our series $50 \%$ patients could do their routine activity on the 2 nd day of operation and only 4 (20\%) patients required 4 days to resume their routine activities. $50 \%$ of our patients resume full activities by the end of 3rd week. Only $25 \%$ of patients who were mostly labourers by profession were able to return to their job by the end of 4 th week. Kingsworth ${ }^{19}$ has stated that patients who are given other methods of repair take on average 7 weeks off work. However it is evident that with mesh hernioplasty our patients are ambulant much earlier and resume to their full professional activities earlier.

Table IV shows in our series of 20 patients, the post-operative complications have remained very low. Post-operative wound infection was $10 \%$ which were superficial and subsided with conservative measures without the need for further antibiotics except 7 days prophylactic antibiotics given postoperatively. Our infection rate is low and comparable to Usher et $\mathrm{al}^{20}$, Larson et $\mathrm{al}^{8}$, Molley et $\mathrm{al}^{4}$. Fifteen per cent patients had residual pain in the $1^{\text {st }}$ month. Residual pain was controlled conservatively and none required removal of mesh. Difficulties during activity were low in $10 \%$ of patients during the 1 st month in patients who were mostly labourers and they did not complain of the same after 1 st month. Thus we learnt that most of the patients could do hard work in 4 weeks after operation. This result certainly shows the advantages of polypropylene mesh hernioplasty over other methods. There was no case of mesh rejection in any of our patients and is comparable to the results obtained by Mtapurkar et $\mathrm{al}^{1} 1991(0 \%)$, Molley et $\mathrm{al}^{4}(0 \%)$. There had been no recurrence of hernia in any of our patients during this period of our follow-up which is comparable to the results obtained by several authors. (Matapukar et $\mathrm{al}^{1}$, Molley et $\mathrm{al}^{4}$, Larson G.M et $\mathrm{al}^{8}$ ).

Disadvantages of the mesh are few. Firstly it is a foreign body and may be rejected. In our study of 
polypropylene mesh repair, we have not encountered a single instance of mesh rejection. Secondly if infection occurred, it could possible necessitate the removal of the mesh. Again this has not occurred in this series. And thirdly the cost factor is found to be little bit higher than other methods of hernia repair. However considering the efficacy of the mesh, if its advantages are taken into consideration, the price is not a barrier.

\section{Summary and Conclusion}

It can be safely concluded from the observation that use of polypropylene mesh is a fairly easy procedure. Wound defects of different sizes could be properly patched. Tissue acceptance and pressure endurance of the graft is very good. Patient compliance except the cost is satisfactory. This procedure is complication free technically easy and recurrence free procedure hence is surely recommended as the most effective method of repair of incisional hernia.

\section{References}

1. Matapurkar, B.G., Gupta, A.K. \&Agarwal, A.K. A new technique of "Marlex®peritoneal sandwich" in the repair of large incisional hernias. World J. Surg. 15, 768770 (1991) doi:10.1007/BF01665314.

2. Townsend RC, Beauchamp BD, Mattox MEK. Clinical surgery of hernia. Sabiston Textbook of Surgery, 19th Edition, Volume II, Elsevier. 2016:1128.

3. Lamont PM, Ellis H. Incisional hernia in re- opened abdominal incisions: An overlooked risk factor. British journal of Surgery. 1988 Apr;75(4):374-6.

4. Molloy RG, Moran KT, Waldron RP, Brady MP, Kirwan WO. Massive incisional hernia: Abdominal wall replacement with Marlex ${ }^{\mathrm{TM}}$ mesh. British journal of surgery. $1991 \mathrm{Feb}$;8(2):242-4.

5. Usher FC, Gannon JP. Marlex mesh, a new plastic mesh for replacing tissue defects: I. Experimental studies. AMA archives of surgery. 1959 Jan 1;78(1):1317.

6. Usher FC, Wallace SA. Tissue reaction to plastics: a comparison of nylon, Orlon, Dacron, Teflon, and Marlex. AMA archives of surgery. 1958 Jun 1;76(6):9979.

7. Usher FC, Gannon JP. Marlex mesh, a new plastic mesh for replacing tissue defects: I. Experimental studies. AMA archives of surgery. 1959 Jan 1;78(1):1317.

8. Larson GM, Harrower HW. Plastic mesh repair of incisional hernias. The American Journal of Surgery. 1978 Apr 1;135(4):559-63.

9. George $\mathrm{CD}$, Ellis $\mathrm{H}$. The results of incisional hernia repair: a twelve year review. Annals of the Royal College of Surgeons of England. 1986 Jul;68(4):185.

10. Lewis RT. Knitted polypropylene (Marlex) mesh in the repair of incisional hernias. Canadian journal of surgery. Journal canadien de chirurgie. 1984 Mar;27(2):155-7.

11. Usher FC, Cogan JE, Lowry TI. A new technique for the repair of inguinal and incisional hernias. Archives of Surgery. 1960 Nov 1;81(5):847-54.

12. Usher FC. Hernia repair with Marlex mesh: an analysis of 541 cases. Archives of surgery. 1962 Mar 1;84(3):325-8.

13. Bucknall et al Burst abdomen and incisional hernia : A prospective study of 1129 major laparotomies. Br. Med. J. 284: 933.1982 Bendavid R et. All Incisional parapubic hernias. Surgery 1990 Nov: 108(5): 898-901

14. Goonetilleke GC. Synthetic mesh in the repair of incisional hernia. The Ceylon medical journal. 1992 Sep;37(3):87-9.

15. Ellis H, Gajraj H, George CD. Incisional hernias: when do they occur? British Journal of Surgery. 1983 May;70(5):2901. 
16. Mudge M, Hughes LE. Incisional hernia: a 10 year prospective study of incidence and attitudes. British Journal of Surgery. 1985 Jan;72(1):70-1.

17. Read RC, Yoder G. Recent trends in the management of incisional herniation. Archives of Surgery. 1989 Apr 1;124(4):485-8.

18. Stoppa RE. The treatment of complicated groin and incisional hernias. World journal of surgery. 1989 Sep 1;13(5):545-54.

19. Kingsworth AN etal: Modern Hernia Managrment Recent Advances In Surgery No. $18,1995$.

20. Usher FC. Hernia repair with knitted polypropylene mesh. SurgGynecol Obstet. 1963;117:239-40. 